Arab Univ. J. Agric. Sci., Ain Shams Univ., Cairo, 13(2), 197 - 206, 2005

\title{
A TAXONOMIC STUDY OF THE GENUS TRIBULUS L. IN EGYPT
}

\section{I- MORPHOLOGICAL FEATURES}

[11]

\author{
Kadria A. Ahmed ${ }^{1}$ and Amaal H. Mohamed ${ }^{1}$
}

\begin{abstract}
This work aims at classifying the genus Tribulus which is represented in Egypt by 7 taxa (6 species \& one variety) viz.: Tribulus terrestris, T.terrestris var. bicornutus, T.pentandrus, T.macropterus, T.megistopterus, T.mollis and T.kaiseri according to the current classical morphological features including those of flower which can lead to a correct taxonomic decision. The work includes detailed comparative vegetative and reproductive morphology of the studied taxa, while drawings representing the extracted results are tried into cumulative plates. Also an artificial indented dichotomous key for the studied taxa is constructed. The key easily differentiated the pentacyclic flowered taxa from the tetracyclic in 2 separated collections. The $1^{\text {st }}$ is composed of 5 taxa in which; nature of pericarp (bony or herbaceous), leaflet pairs into large leaf (7 or 6), calyx (persistant or deciduous), anther connection (basi-or dorsifixed) and others are found effective in identification. On the other hand; calyx imbrication (quincuncial or ascending) and stigma (persistant or deciduous) are used in separating the $2 \mathrm{spp}$. within the $2^{\text {nd }}$ collection.
\end{abstract}

Key words: Genus Tribulus L., Morphological features

\section{INTRODUCTION}

Tribulus of the family Zygophyllaceae is a Linnaean genus (1753) described by 4 species (Tribulus terrestris, T. lanuginosus, T. cistoides and T. maximus) into class Decandria and order Monogynia.

Oliver, (1868) divided the spp. of Tribulus into 2 groups according to the characters of ovary and stigma. Muschler, (1912) classified them into 3 gps. according to the length of petals relative to calyx. Zohary, (1972) stated that the fruit is a schizocarp, mericarps 5 , indehiscent, often separating from axis at maturity, indurated, prickly tuberculated or winged. Seeds solitary, obliquely pendulous, coat membranous and endosperm absent.

On the other hand Engler and Prantle, (1897) and Tackhohm, (1974) recognized 3 gps. of Tribulus spp. according to the characters of carpellary appendages (1- spiny with 2-4 spines for each carpel,

1- Botany Depart., Faculty of Science (Girls), Al-Azhar University, Nasr City, Cairo, Egypt. 
2- with two lateral wings, 3- spineless and wingless). Also Tackholm, (1974) recorded 5 spp. one subsp. and 3 varieties of the genus in Egypt (T. ochroleucus, $T$. pterocarpus, T. longipetalus, T. longipetalus subsp. macropterus, $T$. pentandrus, T. terrestris, T. terrestris var. orientalis, T. terrestris var. robustus \& T. terrestris var. bicornutus.

Abdul Ghafoor (1977) recorded that the flowers are solitary, axillary or pseudo-axillary, pedicellate, actinomorphic, pentamerous, yellow, rarely white, disc annular, fleshly and 10 lobed. Sepals 5, ovate-lanceolate, pubescent, margins membranous caducous or persistent. Petals 5 , patent, obovate, obtuse to \pm lobed at apex or fugacious. Stamens 10 in 2 whorles, rarely 5, inserted between the lobes of the disc, without scaly appendages at base, 5 antisepalous ones shorter, 5 adnate to the base of petals, anthers subbasifixed. Ovary sessile, ovoid or globose, 5-lobed, densely covered by long white apressed hairs, 5-loculed, each locule 2-5 ovuled, style stout - cylindric, 5ridged, 1-4 $\mathrm{mm}$ long, stigma 5 rayed, ovoid - capitate.

El-Hadidi, (1978) recorded that Tribulus comprises about 25 spp. mostly paleotropic while Hosni, (1978) revised 13 spp., 2 subspp. and 6 varieties of the genus in Egypt \& Arabia and added T.kaiseri as a new record sp. to Egypt.

Townsend, (1980), showed that Tribulus spp. are either annual or perennial hairy herbs with opposite pinnate leaves, one bigger than the other at each node.

Boulos, (1995) recorded 7 spp. one subsp. and 3 varieties of the genus in Egypt (T. ochraleucus T. pentandrus, $T$. macropterus var. macropterus T. macropterus var. collenetteae, T. terrestris, $T$. parvispinus var. parvispinus, T. spurius, T. megistopterus subsp. pterocarpus, $T$. bimucronatus, T. mollis and T. kaiseri.

This paper is the first in a study of 2 parts, in this part a comparative study of morphological features of seven taxa of the genus Tribulus is carried out. In the second part, the histological features are going to be studied. The obtained results will be used as taxonomic information to suggest a new proposed system about the taxonomy of Tribulus.

\section{MATERIAL AND METHODS}

The present study is based on fresh and dried materials collected from different localities in Egypt. A list of the studied specimens is given in Table (1). Specimens were kept in the herbarium of the Faculty of Science (Girls), Al-Azhar Univ., Cairo.

Foliar and floral details were examined with the aid of binocular stereomicroscope under incident light. Drawings representing the vegetative and reproductive morphology are original and recorded in cumulative plates (I-III). These were presented in a certain way in order to explain the most important characters analysed.

\section{RESULTS AND DISCUSSION}

\section{(1) Vegetative Morphology: PLATE I}

\section{Whole Plant and Leaf Morphology}

\section{a- Whole Plant: Pl., I Fig. 1}

The growth form varies between annual and biennial white pubescent herbs that have apical robust procumbent branches of sympodial dichasium growth. Annual herbs are: Tribulus terrestris; 
Table 1. List of the collected specimens

\begin{tabular}{|llc|}
\hline \multicolumn{1}{|c}{ Specimens (Taxa) } & \multicolumn{1}{c|}{ Locality } & Date of collection \\
\hline 1- Tribulus terrestris, L. & Cairo, Tayaran st., Nasr City & $20-6-1997$ \\
$\begin{array}{l}\text { 2-T.terrestris var.bicornutus } \\
\text { (Fisch et Mey) Hadidi. }\end{array}$ & Cairo, Tayaran st., Nasr City & 20-6-1997 \\
3- T.pentandrus, Forsskal.* & Kurkur Oasis (Western Desert) & $18-2-1964$ \\
4-T.macropterus, Boiss.* & Red Sea & $29-2-1977$ \\
5- T.megistopterus, Kralik.* & Bir Abraq (Eastern Desert) & $13-1-1930$ \\
6- T.mollis, Ehrenb.* & Kurkur Oasis (Western Desert) & $12-2-1964$ \\
7- T.kaiseri, H. Hosni.* & Wadi El Siq (Ras Sidr, Sinai) & $6-5-1927$ \\
\hline
\end{tabular}

An* mark indicates herbarium specimen (Cairo Univ.).

Fig. (1), T. terrestris var. bicornutus and T. kaiseri while the biennials are: T. macropterus, T. megistopterus and T. mollis in addition to $T$. pentandrus which is both annual \& biennial herb. These may be semi-erect (T. megistopterus) or prostrate (the remainder spp.). Branches may be short; $\leq 25 \mathrm{~cm}$ length (T. terrestris var. bicornutus, T. kaiseri), long; $>50 \mathrm{~cm}$ length (T. terrestris var. bicornutus, $T$. pentandrus) and medium; $\leq 50 \mathrm{~cm}$ length (the remainders), either sparingly hairy (T. megistopterus, T. mollis) or densely (the remainders).

\section{b- Leaf Morphology : Pl. I, Figs. 2-4}

Leaves are usually opposite, petiolate, stipulate, unequal sized at each node and abruptly paripinnate. Large leaf may have 7 pairs of leaflets (Fig. 2,a) in T. terrestris, T. megistopterus but mostly 6paired (Fig. 2,b) in the remainders. Small leaf may be 5-paired (Fig. 2,a) in T. terresteis, 3-parired (Fig. 2,b) in T. me- gistopterus, T.mollis and 4-paired (Fig. $2, c)$ in the remainders. Stipules entire and acute, may be; broadly lanceolate (Fig. 3 ,a) in T. macropterus, ovate - lancealate in $T$. pentandrus while long ovate (Fig. $3, b)$ in the remainders. Leaflet usually entire, subsessile, asymmetric at base and elongate, may be; ovate-acute (Fig. 4,a) in $T$. terrestris, $T$. megistopterus \& $T$. kaiseri or elliptic lanceolate-acuminate (Fig. 4,b) in T. terrestris var. bicornutus, T. pentandrus, T. mollis and or acute in $T$. macropterus.

\section{(2) Reproductive Morphology: Plates: II \& III}

\section{a- Flower characters: $\quad$ PLATE II}

It is usually solitary, ebracteate, pedicellate, pseudoaxillary (Fig. 1), distinct and actinomorphic, either tetracyclic (Fig. 2 ,a) in $T$. pentandrus \& T. kaiseri or pentacyclic (Fig. 2,b) in the remainders. Calyx descending imbricate (Fig. 3,a) in 
Fig. 1. Flower position,

Fig. 2. Floral cycles,

Fig. 3. Fl. Diagrams (sepal \& petal aestivations)

Arab Univ. J. Agric. Sci., 13(2), 2005 
Fig. 4. Sepal shapes, Fig. 5. Petal characters, $\&$ anther lobes length, Fig. 7. L.S. in ovary,
Fig. 6. Stamen position Fig. 8. Stigmatic shapes 
T. megistopterus, ascending in T. pentandrus, valvate (Fig. 3,b) in T. terrestris var. bicornutus, T. macropterus and quincuncial (Fig. 2,b) in the remainders. Sepals may be obovate (Fig. 4,a) in T. terrestris, ovate in $T$. terrestris var. bicornutus and lanceolate acuminate (Fig. 4,b). in the remainders, sometimes deciduous (Fig. 3,a) in T. megistopterus while persistant in the remainders.

Corolla; usually imbricate, either creamy (T. kaiseri) or yellow (the remainders). Petals may be quincuncial (Fig. 3,b) in T. macropterus, descending (Fig. 2,b) in T. terrestris and convolute anticlockwise (Fig. 3,a,c) in the remainders. They are always obovate, either broad-based (Fig. 5,a) in T. terrestris, $T$. terrestris var. bicornutus, T. megistopter$u s$ or narrow based (Fig. 5,b). in the remainders, spathulate in $T$. terrestris, $T$. terrestis var. bicornutus and flattened in the remainders. Apices may be truncate wavy (Fig. 5,c) in T. megistopterus, emarginate in $T$. terrestris, $T$. pentandrus and obtuse (Fig. 5,d) in the remainders.

Androecium; either one whorled (Figs. 2a, 3c) in T. pentandrus, T. kaiseri or two (the remainders). Stamen usually obdiplostimonous with the outer whorl attached to petal base (Fig. 6,a), introrse and open lengthwise. Anther lobes may be equal (Fig. 6,a) in T. terrestris, $T$. macropterus, T. mollis) but unequal (Fig. $6, \mathrm{~b})$ in the remainders, dorsifixed (T. terrestris, $T$. mollis) subbasifixed in $T$. macropterus and basifixed (the remainders).

Gynoecium syncarpous, usually subtended by an annular disc and densely covered by white appressed hairs. Ovary sessile, superior with unequal locules except T. megistopterus, T. macropterus (Fig. 3, a\&b) which have equal locules (each with 2-5 hemitropus ovules on axile placentation (Fig. 7). Style stout cylindrical, 5-ridged, 1-4 mm long, while stigma, either persistent (T. kaiseri) or deciduous (the remainders), may be conical (Fig. 8,a) in T. macropterus, cylindrical (Fig. 8,b) in T. pentandrus, T. mollis, T. kaiseri and obovate (Fig.8,c) in the remainders.

\section{b- Fruit and Seed : PLATE III}

\section{Fruit: Pl. III, Figs. 1,2.}

Usually a schizocarpic capsule, may be discoid (Fig. 1,a) with a spiny form (i) in $T$. terrestis, $T$. terrestris var. bicornutus and a hairy form (ii) in T. kaiseri, \pm broadly ovate (Fig. 1,b) in T. pentandrus and subglobose (Fig. 1,c) in the remainders. Pericarp bony in $T$. terrestris, $T$. terrestris var. bicornutus and herbaceous in the remainders.

Mericarp (Fig. 2) often separated from axis at maturity with the expocarp; winged (Fig. 2,a) in T. macropterus, T. megistopterus, tubercled (Fig. 2,b) in T. kaiseri, T. mollis and spiny (Fig. 2,c) in the remainders.

\section{- Seed: Pl. III, Fig. 3.}

Always solitary, obliquely pendulous, usually obovate, testa membranous, either grooved (Fig. 3,a) in T. terrestris or entire (Fig. 3,b) in the remainders. Colour randged between brown ( $T$. pentandrus, T. megistopterus, T. kaiseri) or creamy (the remainders). 
Fig. 1. Fruit capsule shape,

Fig. 2. Mericarp surface,

Fig. 3. Seed testa

Arab Univ. J. Agric. Sci., 13(2), 2005 


\section{KEY FOR SPECIES}

A- Flower pentacyclic

B- Pericarp bony, plant annual

C- Large leaf with 7 pairs of leaflets, corolla descending imbricate, anther lobes equal and dorsifixed .................................... terrestris

CC- Large leaf 6-paired, corolla anticlockwise, anther lobes unequal and basifixed T. terrestris var. bicornutus

BB- Pericarp herbaceous, plant biennial

D- Calyx persistant, petals narrow based, seeds creamy

E- Ovary with equal locules .........................T. macropterus

EE- Ovary with unequal locules ......................T. mollis

DD- Calyx deciduous, petals wide based, seeds brown .... T. megistopterus

AA- Flower tetracyclic

F- Calyx quincuncial, stigma persistant

T. kaiseri

FF- Calyx ascending, stigma deciduous

T. pentandrus

This result is in conformity with Oliver (1868) who divided the spp. of Tribulus into

2 gps. according to the characters of ovary and stigma.

\section{REFERENCES}

Abdul Ghafoor, A. (1977). Zygophyllaceae in Flora of Libya. No. 38, pp. 3947. Jafri, S.M.H. \& A. El-Gadi (eds.). Bot. Dept., Fac. Sci., Al-Faateh Univ. Tripoli, Libya.

Boulos, L. (1995). Flora of Egypt (Checklist), pp. 81-82. Al-Hadara Publishing, Cairo, Egypt.

El-Hadidi, M.N. (1978). A Proposed Classification for the Genus Tribules $\mathrm{L}$. Taeckholmia, No. 9, pp. 59-66. Publ. Cairo Univ., Giza, Egypt.

Engler, A. and K. Prantle, (1897). Die Naturlichen Pflanzenfamilien, Teil 3 Abteilung (4 und 5), pp. 86-87. Engelmann, Leipzig, Germany.

Hosni Hasnaa, A. (1978). Revision of the Genus Tribulur L. Sections: Alata and Inermis in Egypt and Arabia. pp.
3-53. M.Sc. Thesis, Bot., Dept., Fac. Sci., Cairo, Univ., Giza, Egypt.

Linnaeus, C. (1753). Species Plantarum. Ed.1, p. 386. Holmiae, Sweden.

Muschler, R. (1912). A Manual Flora of Egypt, Vol. 1, pp. 572-574. R. Friedlander \& Sohn, Berlin, Germany.

Oliver, D. (1868). Flora of Tropical Africa, Vol. 1, pp. 283-285. Ashford, London, Great Britain.

Tackholm, Vivi (1974). Students' Flora of Egypt., Ed. 2, pp. 311-313, Publ., Cairo Univ., Giza, Egypt.

Townsend, C.C. (1980). Flora of Iraq, Vol. 1, pp. 289-293. Ministry of Agriculture and Agrarian Reform Baghdad. Republic of Iraq.

Zohary, M. (1972). Flora Palaestina, Vol. 2, pp. 255-256. Israel Academy of Sciences and Humanities, Jerusalem. 
بحلة اتحاد الجامعات العربية للدراسات والبحوث الزراعية ، جامعة عين شمس ، القاهرة ، 13(2) ، 197 - 206 ، 2005

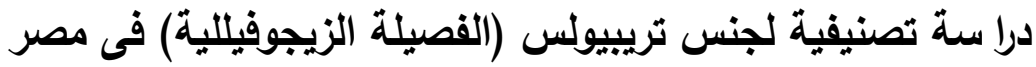
أولا: الصفات المورفولوجية

[11]

$$
\begin{aligned}
& \text { قدرية على أحمد } 1 \text { - أمال حسن محمد1 } 1 \\
& \text { 1- قسم النبات - كلية العلوم (بنات) - جامعة الأزهر - مدينة نصر - القاهزة - مصر }
\end{aligned}
$$

فرق بسهولة بين النباتات خماسية المحيطات

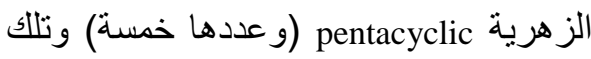

الرباعية tetracyclic (و عددها اثنتان).

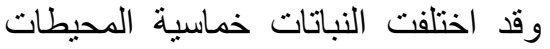
الزهرية فيما بينها بالنسبة لطبيعة الغلاف

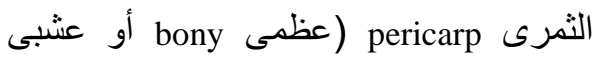
leaflet herbaceous large leaf بالورقة الكبيرة pairs

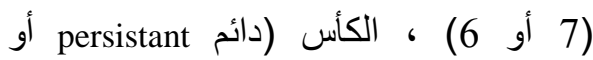
متساقط * deciduous ) و غير ها. أما النوعان رباعيا المحيطات الزهرية

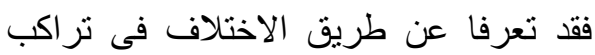

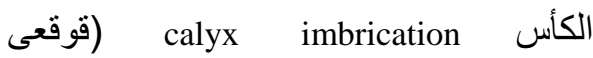
(ascending أو تصاعدى quincuncial ودوام أو تساقط الميسم stigma.
يهـدف هـذا البحـث إلىى تصـنيف جـس تريبيولس genus Tribulus L. أو أبوجريسـة النـامى فـى مصــر و الممثتل بســبعة فئــات تصنيفية من سنة أنواع وصنف: (Tribulus terrestris, T. terrestris var. bicornutus, T. pentandrus, T. macropterus, T. megistopterus, T. mollis \& T. kaiseri).

على أساس الصفات المورفولوجية التقليدية مشتملة على نللك الخاصة بالزهرة

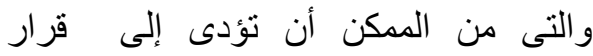
تصنيفى سليم. اشتمل البحث على دراسات تفصيلية مقارنة لمختلف تراكيب الشكل الظاهرى والتى عبر عنها برسومات دقيقة داخل لوحات مجمعة cumulative plates ، كما تم استخلاص مفتاح تعريفى صناعى ومسنن أ.د قاسم فؤاد السحار تحكيم: أ.د سامى عبد القوى 